\title{
Menneskerettigheter, klima og global helse i Legeforeningen
}

\author{
Sentralstyret vedtok i oktober å legge ned utvalg for menneskerettigheter, klima og global helse. Tidligere \\ utvalgsmedlemmer er svært bekymret for fremtidig håndtering av disse viktige, fagovergripende temaene \\ i foreningen.
}

Retten til helse er nedfelt som en grunnleggende menneskerettighet. Krig, konflikt og klimaendringer gjør at stadig flere mennesker utsettes for trusler mot liv og helse. I mange land bruker maktapparatene helsepersonell i tortur eller annen umenneskelig behandling av fanger, opposisjonelle og undertrykte minoriteter. Det finnes mange alvorlige eksempler på at retten til liv og helse står under sterkt press både nasjonalt og globalt.

Legeforeningen har lenge hatt et sterkt engasjement for helse som en grunnleggende menneskerett og for bærekraftige og helsefremmende levekår i Norge og internasjonalt. Dette gjenspeiles i foreningens prinsipprogram gjennom mange år.

I 2012 samlet sentralstyret temaene menneskerettigheter, klima og global helse til ett rådgivende utvalg da tre utvalg ble slått sammen. Utvalget har vært sammensatt av medlemmer med bred faglig erfaring og interessefelter fra ulike arbeidsområder som lege og i Legeforeningens organisasjonsledd. Utvalget har siden da vært aktive i høringssaker og har arbeidet over tid med mange temaer.

Kontinuitet over tid har vært vesentlig for mange av sakene utvalget har arbeidet med. Samtidig har vi gjentatte ganger formidlet, muntlig og skriftlig, til sentralstyret og landsstyret at utvalget ikke nådde frem til andre organisasjonsledd. Vi har også pekt på manglende dialog med sentralstyret og sekretariatets øverste ledelse som et hinder for å gjennomføre vårt mandat.

Legeforeningen er representert i World Medical Association og har der arbeidet med både etikk og et bredt spekter av problemstillinger fra tortur til helsemessige konsekvenser av klimaendringene. Dette engasjementet er viktig, men svært overordnet og lite egnet til å belyse norske forhold og dekke det nasjonale engasjementet Legeforeningen bør ha.

Utvalget har lagt ned mye arbeid i å omsette dette til praktisk handling i Norge og i foreningen de senere årene. Sakene spenner fra miljøsertifisering av legekontor i Norge til samarbeid om utdanning i lavinntektsland, global mental helse og praktisk bistand til den malawiske legeforeningen. Alderstesting av mindreårige asyl- søkere, helsehjelp til personer uten lovlig opphold i Norge samt helsetjenesten ved Trandum interneringsleir er andre aktuelle saker utvalget og Legeforeningen har arbeidet med over flere år.

Vi støtter sentralstyrets målsetting om at arbeidet med menneskerettigheter, klima og global helse skal involvere flere organisasjonsledd mer aktivt. Dette har vi etterspurt i svært mange år. Så vidt vi har sett har sen-

\section{«Samtidig har vi gjen- tatte ganger formidlet til sentralstyret og lands- styret at utvalget ikke nådde frem til andre organisasjonsledd»}

tralstyret ikke informert organisasjonsleddene om at de nå skal overta ansvaret selv. $\mathrm{Vi}$ vil anbefale at foreningen evaluerer det videre arbeidet med menneskerettigheter, klima og global helse etter nedleggelsen av utvalget. Før slutten av inneværende periode bør sentralstyret ha en oversikt over arbeid med aktuelle tema og i hvilken grad man har lyktes med å samle og samordne arbeidet i de forskjellige organisasjonsleddene.

\section{Margit Steinholt \\ margit.steinholt@gmail.com \\ Hilde Engjom \\ Ellen Annexstad \\ Knut-Erling Moksnes \\ Ruth Abraham \\ Barbro Kvaal}

Margit Steinholt (f. 1957) er spesialist i kvinnesykdommer og fødselshjelp, og overlege ved Helgelandssykehuset, Sandnessjøen. Hun er tidligere leder i det nå nedlagte utvalg for menneskerettigheter, klima og global helse.

Forfatter har fylt ut ICME-skjemaet og oppgir ingen interessekonflikter.
Hilde Engjom (f. 1974) er lege ved Kvinneklinikken, Haukeland universitetssykehus og stipendiat ved institutt for global helse og samfunnsmedisin, Universitetet i Bergen. Hun er tidligere leder av utvalg for menneskerettigheter, klima og global helse, medlem i sentralstyret og leder av Yngre legers forening.

Forfatter har fylt ut ICME-skjemaet og oppgir ingen interessekonflikter.

Ellen J. Annexstad (f. 1973) er spesialist i barnesykdommer. Hun er overlege ved Barne- og ungdomsklinikken Sykehuset Østfold og stipendiat ved Enhet for medfødte og arvelige nevromuskulære tilstander, Nevrologisk avdeling, Oslo universitetssykehus. Hun er tidligere styremedlem i Norsk barnelegeforening.

Forfatter har fylt ut ICME-skjemaet og oppgir ingen interessekonflikter.

Knut-Erling Moksnes (f. 1968) er spesialist i indremedisin og i geriatri. Han er sykehjemslege i Gran kommune og har vært med i utvalg for menneskerettigheter, klima og global helse i flere perioder.

Forfatter har fylt ut ICME-skjemaet og oppgir ingen interessekonflikter.

Ruth Abraham (f. 1958) er psykiater og jobber som overlege på Lovisenberg Diakonale Sykehus, psykiatrisk avdeling. Hun er tidligere styremedlem i Norsk psykiatrisk forening og var med å initiere utvalg for transkulturell psykiatri. Hun var medlem av utvalg for menneskerettigheter, klima og global helse i to perioder.

Forfatter har fylt ut ICME-skjemaet og oppgir ingen interessekonflikter.

Barbro Kvaal (f. 1956) er spesialist i allmennmedisin og i samfunnsmedisin. Hun jobber som fastlege og kommuneoverlege. Hun er medlem av legeforeningens turnusråd, og var medlem i utvalg for menneskerettigheter, klima og global helse.

Forfatter har fylt ut ICME-skjemaet og oppgir ingen interessekonflikter.

Mottatt 26.1. 2017, første revisjon innsendt 15.2. 2017, godkjent 16.2. 2017. Redaktør: Kaveh Rashidi.

Publisert først på nett. 